\title{
Perancangan Sistem Charger Otomatis pada Pembangkit Listrik Tenaga Surya
}

\author{
Muhammad Amiruddin \\ Program Studi Teknik Elektro, \\ Fakultas Teknik \\ Universitas PGRI Semarang \\ amiruddin.muhammad@yahoo.com
}

\begin{abstract}
Ringkasan
Salah satu sumber energi terbarukan adalah solar cell yang menggunakan energi sinar matahari yang dapat digunakan untuk sistem pembangkit tenaga surya. Untuk mendukung kerja sistem pembangkit, sebelum energi listrik keluaran solar cell digunakan, perlu ditampung pada accumulator. Sistem charger accumulator otomatis dapat dirancang bangun dengan menggunakan $d c$ to $d c$ converter jenis full bridge converter yang dapat mengatur tegangan keluaran dengan masukan duty cycle PWM picuan 4 saklar elektronis yang terkonfigurasi pada untai tersebut. Modul kendali dibutuhkan untuk memberikan picuan pada full bridge converter berupa PWM dengan pengaturan duty cycle supaya tegangan keluaran stabil sesuai dengan set point yang dikehendaki. Pada pengujian, full bridge converter mempunyai effisiensi maksimal sebesar $97 \%$. Set point kendali tegangan keluaran charger di atur sebesar 13,8 Volt, nilai rata-rata tegangan keluaran sebesar 13,77 Volt, nilai range 0,22 Volt dan mempunyai standar deviasi sebesar 0,06 pada keadaan tunak proses pengendalian.
\end{abstract}

Kata kunci: full bridge converter, solar cell, charger

\section{Pendahuluan}

Sumber energi listrik merupakan sumber yang paling banyak digunakan oleh manusia saat ini. Hal ini disebabkan karena listrik merupakan kebutuhan yang sangat vital dalam hidup manusia. Listrik sangat berperan dalam seluruh bidang kehidupan, sebagian besar peralatan yang dipakai menggunakan listrik sebagai sarana pengoperasiannya. Sementara itu, isu keterbatasan bahan bakar fosil menjadi perhatian penting bagi pengguna energi. Ditambah juga penggunaan bahan bakar fosil yang tidak ramah terhadap lingkungan akibat hasil penggunaan dan cara pengeksplorasiannya. Sampai diusung sebuah gagasan penggunaan sumber energi terbarukan yang cenderung lebih ramah lingkungan daripada bahan bakar fosil. Definisi energi terbarukan adalah sumber energi yang dapat dengan cepat dipulihkan kembali secara alami, dan prosesnya berkelanjutan [1]. Sumber energi terbarukan antara lain, biofuel, biomassa, panas bumi, energi air, energi surya, energi pasang surut, energi ombak, energi angin.

Salah satu sumber energi terbarukan adalah solar cell yang menggunakan energi sinar matahari. Cahaya matahari terdiri atas foton atau partikel energi surya, dimana foton inilah yang dikonversi menjadi energi listrik. Foton-foton mengandung energi yang bervariasi menurut panjang gelombangnya. Energi foto yang diserap oleh sel surya diserahkan sebagian atau seluruhnya kepada electron di dalam surya. Dengan adanya 
energi baru ini maka electron mampu lepas dari posisi normalnya terhadap atom sehingga menjadi arus dalam sirkuit listrik [2].

Pada makalah ini akan dijelaskan tentang perancangan sistem charger accumulator otomatis pada aplikasi pembangkit listrik tenaga surya. Tegangan keluaran dari solar cell mempunyai nilai \pm 18 Volt pada kondisi maksimum, maka perlu dikondisikan untuk proses charging accumulator yang mempunyai 6 sel dan setiap selnya bertegangan 2,30 2.45 Volt [3]. Maka untuk proses charging accumulator diperlukan pengkondisian tegangan dengan rentang tegangan 13,8 - 14,5 Volt. Pada penelitian ini menggunakan $d c-$ $d c$ converter yang bertujuan untuk menurunkan tegangan dengan tipe full bridge converter dan mengatur kestabilan tegangan keluaran sebesar 13,8 Volt.

\section{Desain Sistem}

Pada tulisan ini akan dijabarkan perancangan sistem charger otomatis yang terdiri atas perancangan perangkat keras dan lunak. Perangkat keras terdiri dari modul full bridge converter dan modul kendali. Sedangkan perangkat lunak terdiri dari pengendalian tegangan keluaran charger dan pembangkitan gelombang kotak picuan full bridge converter.

\subsection{Perangkat Keras}

Full bridge Converter. Sistem ini menggunakan dc to dc converter jenis full bridge converter untuk menurunkan tegangan masukan dari solar cell. Full bridge converter menggunakan 4 buah semikonduktor yang bekerja sebagai saklar berpasangan (S1,S4 dan S2,S3), sebuah penyearah gelombang penuh, induktor (L) , Kapasitor (C) dan beban (R). Apabila S1,S4 on sebaliknya S2,S3 off (fase positif) maka tegangan terhubung pada terminal primer transformator sehingga akan membangkitkan tegangan pada terminal sekunder, diode D1 akan bekerja menyearahkan tegangan, mengalirkan arus ke inductor dan kapasitor. Sebaliknya apabila S2,S3 on, S1,S4 off (fase negatif) maka diode D2 akan bekerja menyearahkan tegangan mengalirkan arus ke inductor dan kapasitor. Skematik dari full bridge converter pada Gambar 1. Keluaran tegangan dari full bridge converter dapat dirumuskan sebagai berikut.

$$
\frac{V o}{V s}=2 D \times \frac{N 2}{N 1}
$$

$V o=$ tegangan keluaran (Volt)

$V s=$ tegangan masukan (Volt)

$D$ = Duty cycle (\%)

$N 2=$ jumlah lilitan sekunder

$N 1=$ jumlah lilitan primer 


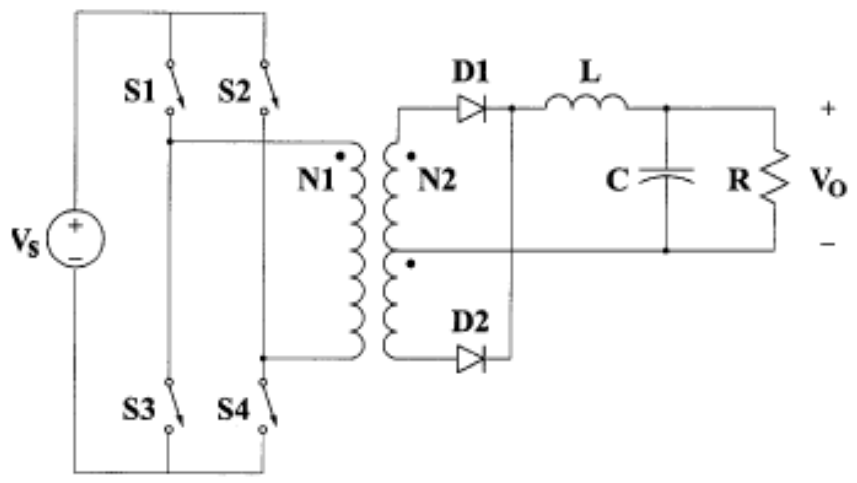

Gambar 1. Skematik full bridge converter [4]

Agar mempunyai efisiensi tinggi, full bridge converter bekerja pada mode CCM (Continuous Conduction Mode). Maka memerlukan besaran induktor $(L)$ dan kapasitor $(C)$ dengan rumus sebagai berikut.

$$
\begin{aligned}
L_{b} & =\frac{(1-2 D) R}{4 f} \\
C_{\text {min }} & =\frac{(1-2 D) V_{\text {out }}}{32 V_{r} L f^{2}}
\end{aligned}
$$

Untuk bekerja pada mode CCM, maka besar $L>L_{b}$ dan $C>C_{\text {min }}$.

Modul Kendali. Modul ini adalah sistem minimum mikrokontroler ATMega128 dengan besar Kristal 16MHz. Modul ini digunakan untuk membangkitkan gelombang kotak picuan full bridge converter dan mengendalikan tegangan keluaran charger. Gelombang kotak dibangkitkan melalui 2 bit port I/O pada sistem minimum ATMega128 yaitu PB5/OC1A dan PB6/OC1B. Kedua port tersebut adalah port yang memiliki fungsi spesial sebagai penghasil PWM (Pulse Width Modulation) pada fitur Timer 1.

\subsection{Perangkat Lunak}

Pengendalian tegangan keluaran charger. Pertimbangan pemilihan jenis kendali untuk pengendalian tegangan keluaran sesuai dengan blok diagram pada Gambar 2 berikut.

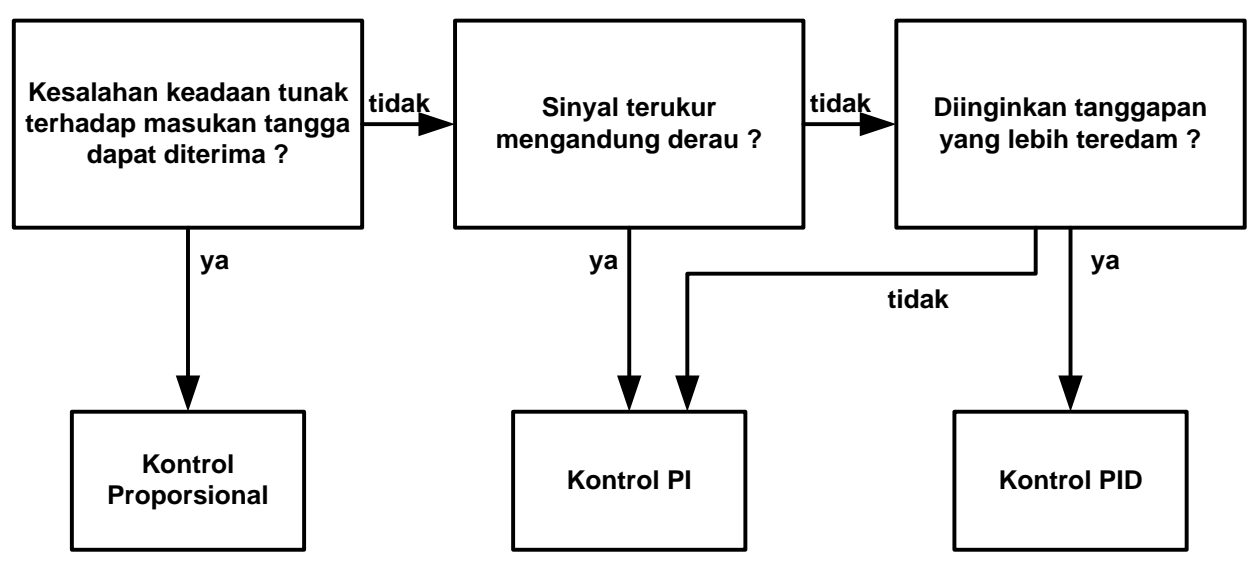

Gambar 2. Pemilihan jenis kendali [5] 
Keluaran dari charger dipengaruhi dari besar masukan sistem yang merupakan keluaran solar cell. Keluaran solar cell sangat dipengaruhi dari sinar matahari yang pada situasi normal, dipengaruhi waktu (pagi, siang, sore). Perubahan keluaran dari solar cell dapat dilihat pada Gambar 3. Dapat disimpulkan dari tabel tersebut, bahwa perubahan masukan sistem sangat lambat, sehingga sinyal terukur pada sistem tidak mengandung derau yang signifikan dan tidak memerlukan peredaman lebih. Maka dipilihlah jenis kendali PI (Proporsional Integral).

Tabel 1. Keluaran solar cell pada pengisian accumulator [6]
\begin{tabular}{|c|c|c|c|c|}
\hline $\begin{array}{c}\text { Jam } \\
\text { pengujian }\end{array}$ & $\begin{array}{c}\text { Solar } \\
\text { cell 1 } \\
(\mathrm{v})\end{array}$ & $\begin{array}{c}\text { Solar } \\
\text { cell 2 } \\
(\mathrm{v})\end{array}$ & $\begin{array}{c}\text { Solar } \\
\text { cell 3 } \\
(\mathrm{v})\end{array}$ & $\begin{array}{c}\text { Solar } \\
\text { cell 4 } \\
(\mathrm{v})\end{array}$ \\
\hline $7: 50$ & 14.46 & 14.42 & 14.37 & 14.32 \\
\hline $8: 20$ & 15.43 & 15.14 & 14.71 & 14.71 \\
\hline $8: 50$ & 14.47 & 14.44 & 14.13 & 14.13 \\
\hline $9: 20$ & 15.58 & 15.46 & 15.34 & 15.31 \\
\hline $9: 50$ & 16.24 & 16.5 & 15.64 & 15.64 \\
\hline $10: 20$ & 18.47 & 18.08 & 17.83 & 17.03 \\
\hline $10: 50$ & 18.2 & 17.95 & 17.03 & 17.06 \\
\hline $12: 20$ & 18.21 & 17.89 & 17.06 & 17.17 \\
\hline $12: 50$ & 17.84 & 17.47 & 17.17 & 16.85 \\
\hline $13: 20$ & 17.81 & 17.5 & 17.02 & 16.91 \\
\hline $13: 50$ & 18.05 & 17.72 & 17.12 & 16.98 \\
\hline $14: 20$ & 17.78 & 17.66 & 16.98 & 16.88 \\
\hline $14: 50$ & 17.87 & 17.48 & 17.02 & 16.92 \\
\hline $15: 20$ & 17.47 & 17.15 & 16.69 & 16.46 \\
\hline $15: 50$ & 16.02 & 15.87 & 15.68 & 15.13 \\
\hline $16: 20$ & 13.44 & 13.26 & 13.11 & 12.11 \\
\hline $16: 50$ & 10.4 & 10.12 & 10.25 & 10.03 \\
\hline $17: 00$ & 8.46 & 8.76 & 8.23 & 8.14 \\
\hline
\end{tabular}

Dengan kontrol PI, diharapkan respon sistem meningkat, dan nilai offset keadaan tunak dapat mengecil. Kontrol PI cocok untuk kondisi sistem tanpa derau, karena tidak terdapat elemen kontrol derivatif untuk mengantisi perubahan nilai error yang cepat pada derau. Blok diagram kontrol PI dapat dilihat pada Gambar 3. Rumus untuk keluaran pengontrol adalah sebagai berikut.

$$
C O=K p e+K i \int e d t
$$

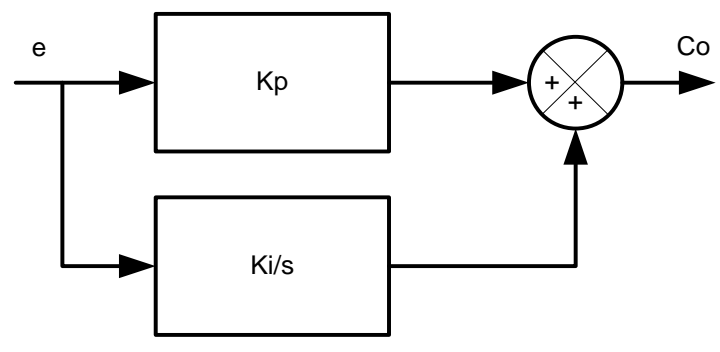

Gambar 4. Blok diagram kontrol PI [5]

Pembangkitan picuan gelombang kotak. Dalam pembangkitan picuan gelombang kotak, diperlukan fitur dalam mikrokontroler ATMega128 berupa ADC untuk mendapatkan nilai proses (PV) dari tegangan keluaran aktual charger. Interupsi Timer 3 untuk proses perhitungan error (e) dimana error adalah selisih dari nilai setpoint (SP) dan nilai proses (PV), integral error (i_e) yaitu akumulasi nilai error, dan keluaran pengontrol 
(CO). Interupsi Timer 2 melalui register TCNT2 untuk menentukan besar frekuensi (Hz) picuan dan PWM Timer 1 melalui register OCR1AL dan OCR1BL untuk menentukan besar duty cycle picuan. Maka secara keseluruhan perangkat lunak bekerja sesuai dengan diagram alir pada Gambar 5.

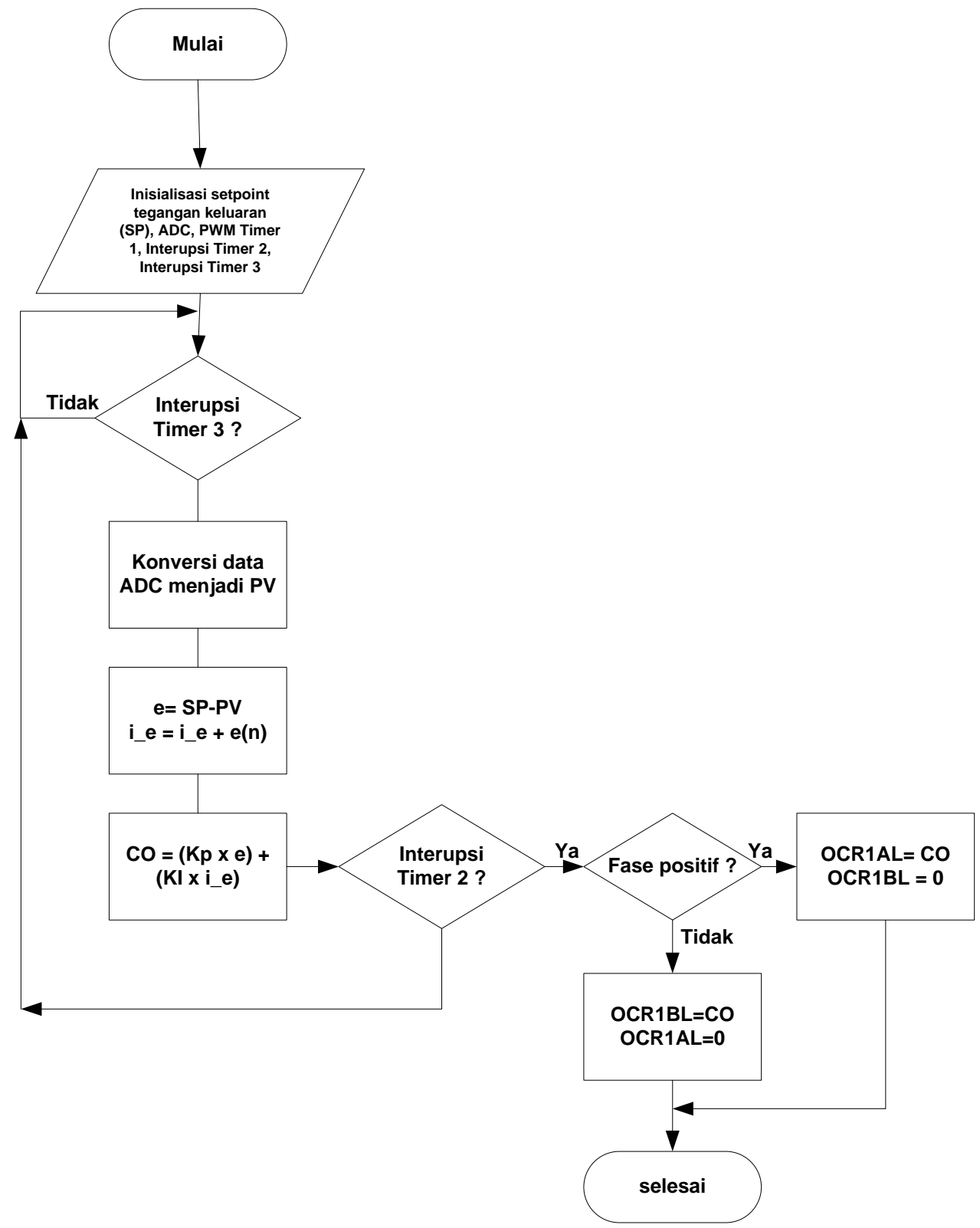

Gambar 5. Diagram alir kerja perangkat lunak

\section{Hasil dan Analisa}

Simulasi dilakukan menggunakan perangkat lunak PSIM 9.0.3 untuk merancang untai full bridge converter. Untai skematik dan ilustrasi picuan 4 saklar seperti pada Gambar 6. Duty cycle yang dapat diaplikasi pada picuan maksimal sebesar $50 \%$ untuk 
menjaga agar untai tidak terjadi short circuit pada saat pasangan saklar $\mathrm{S} 1, \mathrm{~S} 4=\mathrm{ON}$ dan S2,S3 = OFF atau sebaliknya S1,S4 = ON dan S2,S3 = OFF.
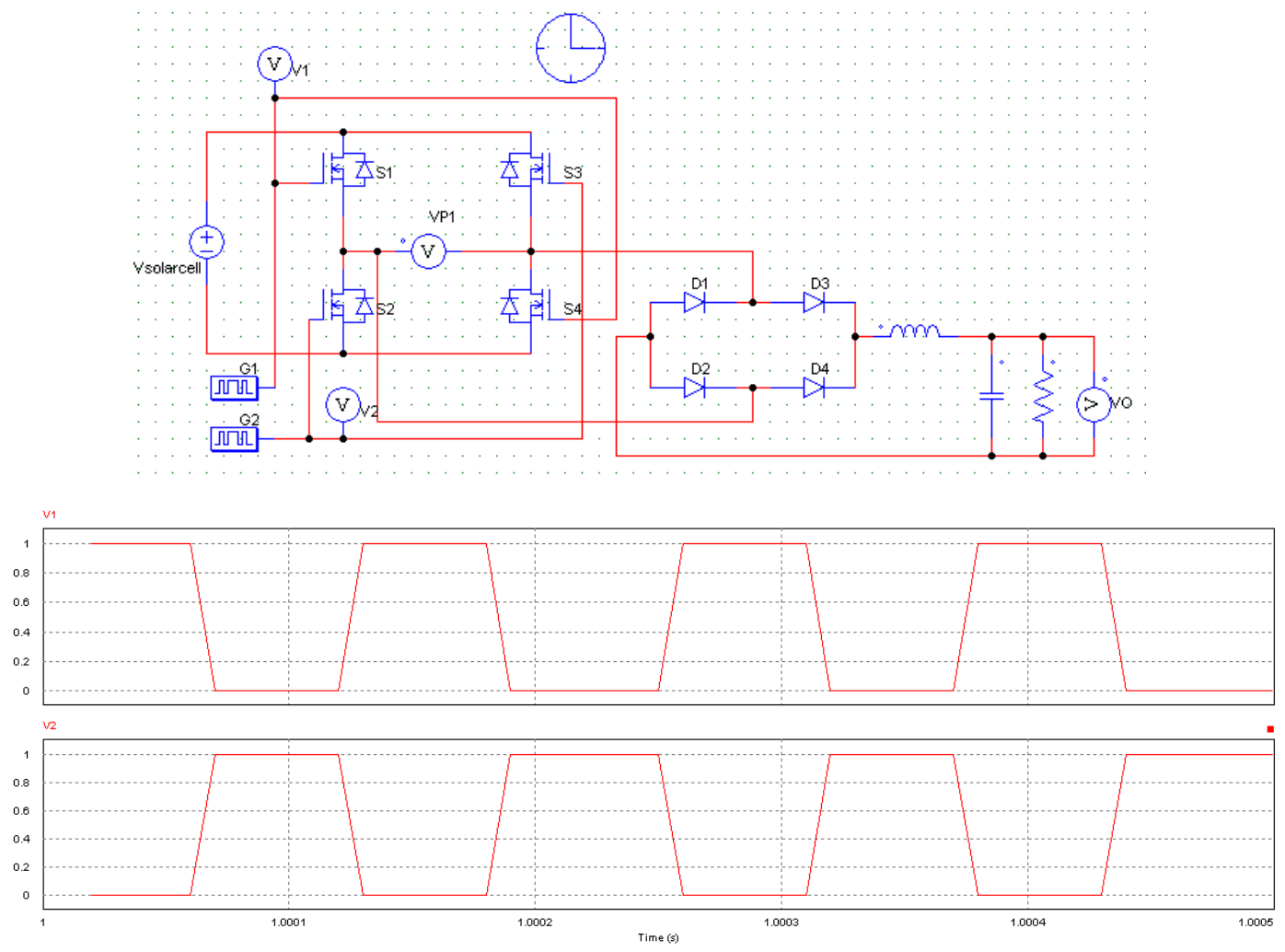

Gambar 6. Simulasi PSIM full bridge converter dengan duty cycle picuan $50 \%$ frekuensi $8 \mathrm{k} \mathrm{Hz}$

Setelah melakukan simulasi, maka selanjutnya dilakukan realisasi perangkat keras untai full bridge converter. Pengujian dilakukan dengan pemberian picuan dengan rentang duty cycle $15 \%$ - 50\% dan melakukan pengukuran beberapa parameter seperti pada Tabel 2.

Tabel 2. Hasil pengujian perangkat keras full bridge converter $\mathrm{Vin}=17,5$ dan $\mathrm{R}=50 \mathrm{ohm}$

\begin{tabular}{|c|c|c|c|c|}
\hline $\begin{array}{c}\text { Duty } \\
\text { Cycle }\end{array}$ & Vout & Iin & Iout & $\begin{array}{c}\text { Efisiensi } \\
\text { (Pout/Pin) }\end{array}$ \\
\hline 15 & 3.36 & 0.02 & 0.067 & 0.64512 \\
\hline 20 & 4.6 & 0.035 & 0.092 & 0.690939 \\
\hline 25 & 6.37 & 0.055 & 0.127 & 0.843156 \\
\hline 30 & 7.91 & 0.085 & 0.158 & 0.841252 \\
\hline 35 & 9.41 & 0.12 & 0.188 & 0.843315 \\
\hline 40 & 11.11 & 0.15 & 0.222 & 0.940435 \\
\hline 45 & 12.78 & 0.195 & 0.256 & 0.957236 \\
\hline 50 & 14.28 & 0.24 & 0.286 & 0.97104 \\
\hline
\end{tabular}

Tahap akhir, keseluruhan sistem tersusun seperti pada blok diagram pada Gambar 7 . Solar cell memberikan tegangan masukan bagi full bridge converter. Full bridge converter memberikan tegangan keluaran untuk men-charge accumulator. Dan sebagai pusat sistem, modul kendali telah dilengkapi perangkat lunak pengendali kendali tegangan keluaran dan pembangkitan picuan 


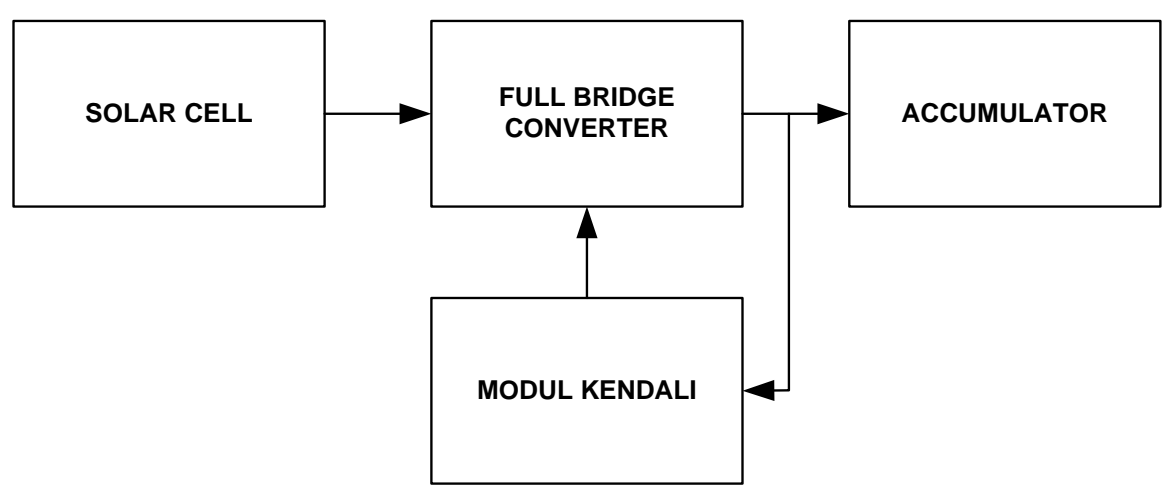

Gambar 7. Blok diagram keseluruhan sistem

Modul kendali menerima umpan balik berupa tegangan keluaran charger melalui port ADC untuk diproses dalam elemen kendali jenis Proporsional Integral yang menghasilkan duty cycle PWM melalui 2 bit port I/O (PB5/OC1A dan PB6/OC1B ). Hasil kendali terlihat pada grafik pada Gambar 8. Pada pengujian, tegangan awal adalah tegangan awal accumulator yang hendak di charge yaitu sebesar 11,5 volt, kemudian secara berangsur tegangan naik mendekati set point sebesar 13,8 volt.

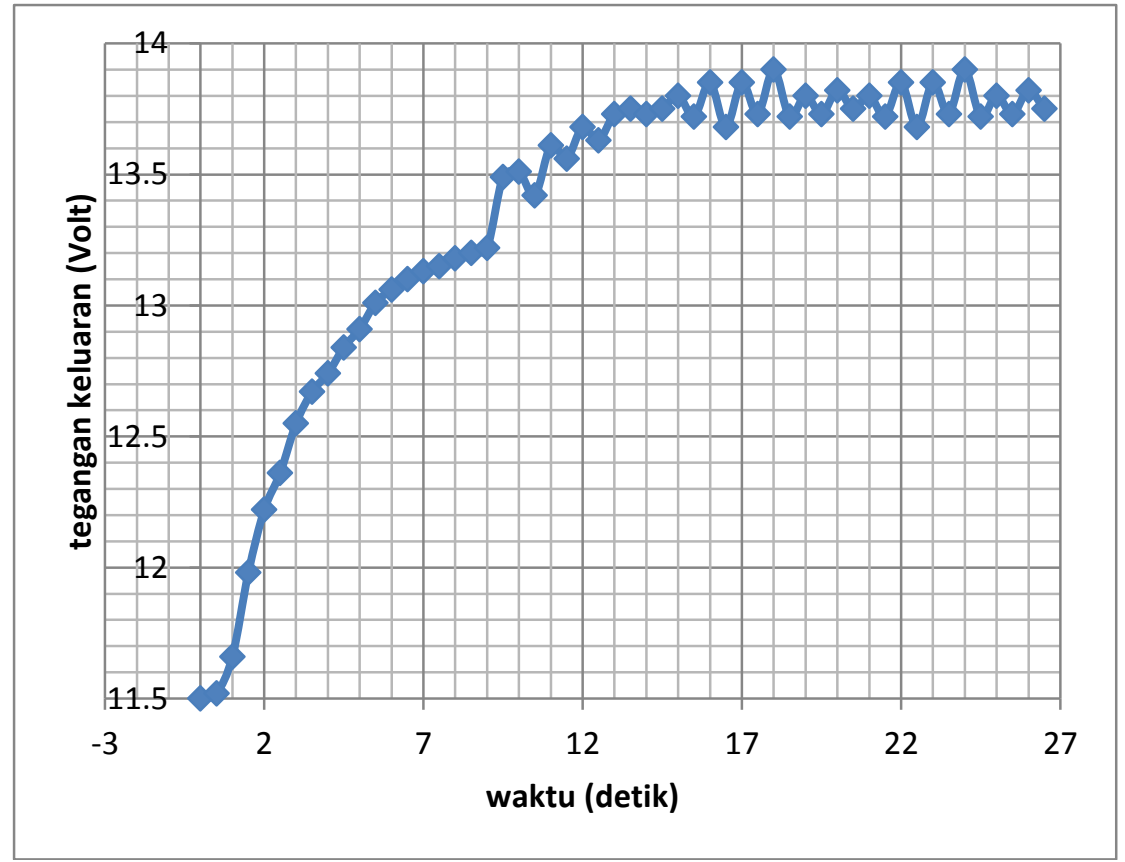

Gambar 8. Respon kendali tegangan keluaran charger dengan set point 13.8 volt

Dari data hasil pengendalian pada Gambar 8, besar penyimpangan data dari nilai setpoint dapat diketahui dengan perhitungan ukuran penyebaran dengan parameter jarak (range), dan standar deviasi $(\sigma)$. Persamaan jarak dan standar deviasi adalah sebagai berikut.

$$
\begin{aligned}
& \text { range }=\text { nilai max }- \text { nilai } \min \\
& \text { Standar deviasi }(\sigma)=\sqrt{\frac{\sum(X-u)^{2}}{N}}
\end{aligned}
$$


dengan:

$X=$ nilai data hasil pengendalian

$\mu=$ nilai rata-rata hitung

$N=\quad$ jumlah total data

Dengan parameter jarak (range), secara sederhana, dapat diketahui ukuran penyebaran data hasil pengendalian. Semakin besar jarak (range) berarti pengendalian semakin tidak presisi karena data hasil pengendalian melebar. Dengan parameter standar deviasi $(\sigma)$, dapat diketahui keakuratan dan kepresisian dari pengendalian. Dalam perhitungan standar deviasi, melibatkan rata-rata hitung data. Apabila rata-rata hitung data mendekati dengan nilai setpoint maka pengendalian semakin akurat. Semakin kecil standar deviasi, pengendalian semakin presisi, karena selisih data dengan rata-rata hitungnya adalah kecil. Dari pengujian pengendalian, pada saat keadaan tunak terhitung rata-rata hitung data tegangan keluaran sebesar 13,77 Volt. Nilai range tegangan keluaran terhitung sebesar 0,22 Volt dan standart deviasi sebesar 0,06.

\section{Kesimpulan}

Berdasarkan data Tabel 1, Pengisian accumulator dapat dilakukan pada pukul 10:20 sampai dengan 15:20 dengan tegangan masukan charger rata-rata \pm 17,5 Volt dari solar cell. Pada full bridge converter dapat dicapai tegangan keluaran sebesar 13,8 Volt dengan pengendalian duty cycle antara $45 \%$ - 50\% dengan efisiensi $95 \%$ sampai dengan $97 \%$ sesuai pada Tabel 2. Pada proses pengendalian, saat keadaan tunak terhitung rata-rata hitung data sebesar 13,77 Volt, nilai range sebesar 0,22 Volt dan standart deviasi sebesar 0,06 Volt.

\section{Daftar Pustaka}

[1] Wikipedia, Energi terbarukan [online], http://id.m.wikipedia.org/wiki/Energi_ terbarukan, diakses tanggal : 1 September 2015.

[2] Zulkifli, Perencanaan Pemanfaatan Energi Surya sebagai Energi Alternatif untuk Kebutuhan Listrik pada KLM.Pinisi 360 GRT, 2013.

[3] Batterey University, Charging Lead Acid [online], http://batteryuniversity.com/ learn/article/charging_the_lead_acid_battery ,diakses tanggal : 1 September 2015.

[4] M.H. Rashid,Power Electronics Handbook, San Diego :Academic Press,2001.

[5] W. Bolton, Sistem Instrumentasi dan Sistem Kontrol, Jakarta : Erlangga,2006.

[6] P.Y. Hidayat, E. Wahjono, A.R. Nansur, Rancang Bangun Suatu Sistem Pemanfaatan Sumber Energi Tenaga Surya sebagai Pendukung Sumber PLN untuk Rumah Tangga berbasis Mikrokontroler, 2011. 